\title{
Level of Knowledge of Junior High School Students About the Effects of Ultraviolet Radiation on the Skin and the Use of Sunscreen
}

\author{
Aulia Annisa Manurung ${ }^{1}$, Ariyati Yosi ${ }^{2}$, Imam Budi Putra ${ }^{3}$, Imelda Rey ${ }^{4}$ \\ ${ }^{1}$ Faculty of Medicine, Universitas Sumatera Utara, Medan, North Sumatera, Indonesia \\ ${ }^{2}$ Department of Dermatology and Venereology, Faculty of Medicine, Universitas Sumatera Utara, Medan, North Sumatera, Indonesia \\ ${ }^{3}$ Department of Dermatology and Venereology, Faculty of Medicine, Universitas Sumatera Utara, Medan, North Sumatera, Indonesia \\ ${ }^{4}$ Department of Internal Medicine, Faculty of Medicine, Universitas Sumatera Utara, Medan, North Sumatera, Indonesia
}

DOI: 10.29322/IJSRP.12.01.2022.p12124

http://dx.doi.org/10.29322/IJSRP.12.01.2022.p12124

\begin{abstract}
Background. Ultraviolet light is an electromagnetic wave emitted from sunlight which is divided into 3 wavelengths. UV wavelengths, divided into UVA rays, UVB rays and UVC rays. UVC rays will be trapped in the ozone layer and UVA radiation can reach $(90-95 \%)$ while at UVB will be less $(<10 \%)$. The body needs special protection from UV radiation, especially on organs that are exposed to direct sunlight, namely the skin. Sunscreen is a compound that functions as skin protection from excessive sun exposure, especially from exposure to ultraviolet (UV) rays. Sunscreen is divided into 2 types, namely physical sunscreen and chemical
\end{abstract} sunscreen.

Aim. This study aimed to investigate the level of knowledge of junior high school students about the effects of UV radiation and the use of sunscreen.

Research methods. This study uses a descriptive observational research method with a cross sectional approach that describes the level of knowledge of junior high school students about the effects of UV radiation and the use of sunscreen. Sampling will be carried out at one time using data collection techniques through questionnaires. The data obtained will then be processed and analyzed with the SPSS computer program.

Results. The total samples we investigated were 223 respondents. As many as $61 \%$ of respondents have a sufficient level of overall knowledge. The level of knowledge of respondents about the effects of UV radiation on the skin is in the sufficient category with a percentage of $62.3 \%$. The level of knowledge of students regarding the use of sunscreen on the skin is in the sufficient category with a percentage of $55.2 \%$.

Conclusion. The level of knowledge of the students of public junior high school 2 in Pematangsiantar city for the academic year $2021 / 2022$ as a whole is at the level of knowledge in the sufficient category.

Index Terms- Knowledge Level; UV Rays; Sunscreen

\section{INTRODUCTION}

I ndonesia is a country that has a high abundance of sunlight every year and makes Indonesia a tropical country with high levels of UV radiation [1]. The sun is the main source of UV light. Sunlight produces UV rays which are actually needed to produce vitamin D in our body but in moderate amounts [2]. Chronic exposure to ultraviolet rays from the sun will result in changes in the structure, composition of the skin and oxidative stress on the skin. Effects such as erythema, pigmentation and photosensitivity, as well as long-term effects in the form of premature aging and skin cancer [3]. UV radiation is divided into 3 types based on their wavelength. If the emitted waves are shorter, then the radiation will be more dangerous but will be trapped in the ozone layer and not exposed to the skin directly, on the contrary, if the wavelength is longer, it will be more likely to be directly exposed to the skin and reach the earth's surface.

The increasing number of population, and the rapidly growing industry, have an impact on increasing pollution which will also reduce the atmosphere, especially the ozone layer [4]. The atmosphere will be selective against UV rays, so it will affect the UV waves that reach the earth's surface. Comparison of UVA and UVB will be quite significant. UVA radiation can reach (90-95\%) while at UVB it will be less $(<10 \%)$ [5]. As a result of exposure to UV rays that are too high, the body needs special protection because too much UV radiation will be able to damage the DNA of skin cells in humans. Very high exposure is not able to be protected by the immune system perfectly, so it will cause thickening and aging of the skin and can lead to skin cancer [2]. With an increase in exposure to ultraviolet radiation, the incidence of skin cancer seems to be increasing [6]. The skin cancer in Indonesia is the third most common cancer case 
after cervical cancer and breast cancer. In this study, the most common skin cancer was basal cell cancer (81\%), followed by squamous cell carcinoma (16\%) [7]. The research of Sibarani et al. At Haji Adam Malik General Hospital Medan for 3 years (2005-2007) there were $5.74 \%$ of skin cancer patients out of 296 cases of skin tumors, consisting of 106 male patients (35.6\%) and 190 female patients (64. 4\%) [8].

Sunscreen is needed by the body to protect the body from UV rays. There are 2 types of content in sunscreens that differentiate the function of the sunscreen. Physical sunscreens and chemical sunscreens are distinguished by their function and ingredient content. Physical sunscreens contain titanium dioxide and work to block UV rays from penetrating the skin directly. Chemical sunscreens contain avobenzone and octisalate which are able to penetrate to the epidermis and dermis of the skin and work by absorbing UV rays that enter the skin [9]. Adolescence is a very important phase in maintaining health, so that body health will be maintained until it continues into the adult phase.

Knowledge is the result of knowing from an individual's sensing of an object that can be known through the five senses it has and most of it is obtained through the sense of hearing and the sense of sight states that there are several aspects of a person's level of knowledge, namely knowledge, comprehension, application, analysis, synthesis, and evaluation [10].

Based on the background that has been described, the researcher feels like doing research and is interested in knowing the level of knowledge about the effects of UV radiation on the skin and the use of sunscreen in junior high school students. Sample of the level of knowledge of students is taken from a public junior high school 2 in Pematangsiantar city, because the researchers felt that knowledge about UV radiation and daily use of sunscreen was still lacking in adolescent girls in the Pematangsiantar area. Researchers will measure the level of knowledge through a questionnaire sheet. The researcher hopes that the purpose of this research is achieved well and can be useful and used by further researchers as well as possible.

\section{METHODOLOGY}

This is descriptive research that uses a cross-sectional research design. Place of research in this study was carried out at public junior high school in Pematangsiantar city, named SMP Negeri 2 Pematangsiantar. Sample size in this study will use the Slovin formula, so the sample size in this study is 223 respondents. In determining the sample, the sampling technique used is by using consecutive sampling. The data collection method used in this study used primary data obtained from research respondents through questionnaires and secondary data obtained from the school regarding the total number of students of public junior high school 2 in Pematangsiantar city for the 2021/2022 academic year. Data analysis was carried out with the help of a computer system through several stages, including editing, coding, entry, cleaning, and saving. The data generated from this study, processed by univariate analysis which will be presented in the form of a frequency distribution table.

\section{RESULT AND DISCUSSION}

The distribution of sample characteristics in this study was grouped into 3 (three) characteristics, namely respondents based on age, based on generation, and based on the use of sunscreen. Based on age, can be seen in the following table 1.

Table 1. Distribution of research sample characteristics by age

\begin{tabular}{ccc}
\hline Age & Total $(\mathrm{n})$ & Percentage $(\%)$ \\
\hline 11 & 7 & 3,1 \\
12 & 46 & 20,6 \\
13 & 76 & 34,1 \\
14 & 85 & 38,1 \\
15 & 9 & 4,0 \\
\hline Total & 223 & 100 \\
\hline
\end{tabular}

Based on the table above, in this study, the respondents were aged between 11 to 15 years. The majority of respondents who filled out the questionnaire were 14 years old with a percentage of $38.1 \%$. Furthermore, the distribution of the characteristics of the research sample by batch can be seen in the table below 2 .

Table 2. Distribution of research sample characteristics by batch

\begin{tabular}{ccc}
\hline Class & Total $(\mathrm{n})$ & Percentage $(\%)$ \\
\hline VII & 34 & 15,2 \\
VIII & 90 & 40,4 \\
IX & 99 & 44,4 \\
\hline
\end{tabular}


Based on the table above, in this study, it was found that respondents who filled out the class IX questionnaire were (44.4\%), class VII was (40.4\%) and class VII was (15.2\%). Furthermore, the distribution of the characteristics of the research sample based on the use of sunscreen can be seen in the table 3 .

Table 3. Distribution the characteristics of the research sample that based on the use of sunscreen

\begin{tabular}{ccc}
\hline Use of sunscreen & Total $(\mathrm{n})$ & Percentage $(\%)$ \\
\hline Do not use & 165 & 74,0 \\
Use & 58 & 26,0 \\
\hline Total & 223 & 100
\end{tabular}

Based on the table above, in this study, the results obtained were 58 respondents $(26.0 \%)$ who used sunscreen and 165 respondents $(74.0 \%)$ did not use sunscreen. The knowledge of the respondents in this study was assessed based on 25 questions which included knowledge about the effects of UV radiation and the use of sunscreen. Previously, the validity and reliability of the questionnaire had been tested and the results showed that all the questions on the questionnaire were valid and reliable. The respondent's level of knowledge will be categorized as good if the percentage of the number of correct answers is $75 \%-100 \%$ is said to be sufficient if the respondent's correct answer reaches a percentage of $50 \%-74 \%$ and is said to be lacking if the level of knowledge is considered lacking if the percentage of the number of correct answers is $<50 \%$ [11].

Table 4. Knowledge Level of Students on the Effects of UV Rays on the Skin and the Use of Sunscreen on the Skin

\begin{tabular}{ccc}
\hline Knowledge & N (person) & Percentage $(\%)$ \\
\hline Good & 66 & 29,6 \\
Enough & 136 & 61,0 \\
Not enough & 21 & 9,4 \\
\hline Total & 223 & 100
\end{tabular}

Based on the table above, as many as 66 respondents (29.6\%) have a good level of knowledge, as many as 136 respondents $(61.0 \%)$ have a sufficient level of knowledge and as many as 21 respondents $(9.4 \%)$ have a low level of knowledge about the effect UV rays on the skin and the use of sunscreen in overcoming the adverse effects of UV rays on the skin. This level of knowledge was taken from a questionnaire totaling 25 questions regarding questions about the effect of UV rays on the skin and the use of sunscreen in protecting the skin from UV radiation.

Table 5. Knowledge Level of Students Regarding the Effects of UV Radiation on Skin

\begin{tabular}{ccc}
\hline Knowledge & N (person) & Percentage $(\%)$ \\
\hline Good & 57 & 25,6 \\
Enough & 139 & 62,3 \\
Not enough & 27 & 12,1 \\
\hline Total & 223 & 100
\end{tabular}

Based on the table above, as many as 57 respondents (25.6\%) have a good level of knowledge, as many as 139 respondents $(62.3 \%)$ have a sufficient level of knowledge and as many as 27 respondents $(12.1 \%)$ have a low level of knowledge. This level of knowledge was taken based on questionnaires numbered 1 to 15 which were questions about the effects of UV radiation on the skin.

Table 6. Knowledge Level of Students Regarding the Use and Benefits of Sunscreen on the Skin

\begin{tabular}{ccc}
\hline Knowledge & N (person) & Percentage $(\%)$ \\
\hline Good & 75 & 33,6 \\
Enough & 123 & 55,2 \\
Not enough & 25 & 11,2 \\
\hline Total & 223 & 100
\end{tabular}

Based on the table above, as many as 75 respondents (33.6\%) have a good level of knowledge, as many as 123 respondents $(55.2 \%)$ have a sufficient level of knowledge and as many as 25 respondents $(11.2 \%)$ have a low level of knowledge regarding the use of and the benefits of sunscreen on the skin. This level of knowledge was taken based on questionnaires numbered 16 to 25 which were questions about sunscreen. 
Knowledge is everything that is known and obtained from sensing certain objects. Basically, knowledge is the result of the process of seeing, hearing, feeling, and thinking which will be the basis of human behavior and action [12]. The previous research conducted by Pramesti in 2019 stated that as many as $87 \%$ of students had a good level of knowledge about the use of sunscreen [13]. The results of the research conducted by Pramesti contradicted the results of this study due to the level of knowledge of students who had gained wider knowledge of sunscreens and their use compared to junior high school students. However, the results of this study are in line with research conducted by Wadoe et al in 2019 which stated that the majority of the knowledge and behavior of respondents in this survey in using sunscreen was still not good, so education about the importance of using sunscreen was needed to improve the current condition of respondents' knowledge [14].

Naturally, the skin will try to protect its surface and organs underneath from the dangers of UV rays, namely by forming melanin pigment grains that will reflect sunlight back. However, if the formation of melanin occurs excessively and continuously, it will form black spots on the skin. Therefore, sunscreen compounds are needed to protect the skin from direct UV radiation [15]. The first negative impact of exposure to UV rays is that they can burn the skin and that is the reason why when you go out during the day your skin will feel hot and red. After cooling, our skin will darken due to the burning. Second, UV rays can cause skin to become dull, dry, and wrinkled [14].

Sunscreen preparations are one of the cosmetics used to effectively reflect or absorb sunlight, especially in the ultraviolet wave area so that it can prevent skin disorders caused by sunlight [16]. The SPF value indicates how long a product is able to protect or block UV rays that can cause sunburn. The time it takes to make the skin burn without using sunscreen varies for each individual. This is influenced by the type of skin or a person's race factor. People with darker skin tend to be more resistant to sunlight than people with light skin. This happens because dark skin contains a lot of pigment cells called melanin. Melanin is a natural sunblock that can reflect UV radiation, especially UVA and UVB. Therefore, in people with dark skin, the time it takes for the skin to burn if not wearing sunscreen is longer than in people with lighter skin color [17].

Notoadmojo mentions that knowledge has 6 levels, namely, knowing which is defined as knowledge only limited to recalling what has been previously learned and is the lowest level, understanding, namely the ability to explain and interpret objects that have been studied correctly, applications where knowledge can be applied and applied. in the actual situation, analysis is to describe in detail and specifically the material that has been studied previously, synthesis, namely someone is able to link various elements or elements of existing knowledge into a new pattern that is more comprehensive, and evaluation which can assess and measure an object based on criteria. available or the result of individual decisions.

\section{CONCLUSION}

Based on the analysis of the data obtained from this study, several conclusions can be drawn, namely the level of knowledge of students of public junior high school 2 in Pematangsiantar city for the academic year 2021/2022 as a whole at the level of knowledge in the sufficient category, the level of knowledge about the effects of UV radiation on the skin, the results show that the most are categories enough as many as 139 respondents with a percentage of $62.3 \%$, as well as the level of knowledge about the use of sunscreen and the benefits of sunscreen in overcoming UV radiation, the most results were obtained at the level of knowledge in the sufficient category as many as 123 respondents with a percentage of $55.2 \%$.

\section{REFERENCES}

[1] Isfardiyana, S. H. and Safitri, S. R. 'Pentingnya melindungi kulit dari sinar ultraviolet dan cara melindungi kulit dengan sunblock buatan sendiri', Jurnal Inovasi dan Kewirausahaan, 3(2), 2014 pp. 126-133. Available at: https://journal.uii.ac.id/ajie/article/view/7819.

[2] World Meteorological Organization. The Sun, our well-being and health. 2019 Available at: https://public.wmo.int/en/sun-our-well-being- and-health [Accessed May 10, 2021]

[3] Rahmawati, A. M., \& Meigita, A. Analisis Aktivitas Perlindungan Sinar UV Sari Buah Sirsak (Annona muricata L.) Berdasarkan Nilai Sun Protection Factor (SPF) Secara Spektrofotometri UV-VIS. Jurnal Fitofarmaka 2018 5(2).

[4] Seran, Pasangka, Y. Y. T. ., Bartholomeus, \& Imam, H. ZKarakteristik Paparan Radiasi Sinar Ultraviolet A (UV-A) dan Cahaya Tampak di Kota Kupang. Jurnal Biotropikal Sains, 2018. 15(3), 49-56.

[5] BMKG. Indeks Sinar Ultraviolet (UV). Diambil dari BMKG 2020. website: https://www.bmkg.go.id/cuaca/indeks-uv.bmkg

[6] Wilvestra, S., Lestari, S., \& Ennesta, A. Studi Retrospektif Kanker Kulit di Poliklinik Ilmu Kesehatan Kulit dan Kelamin RS Dr. M. Djamil Padang Periode Tahun 2015-2017. 2018

[7] Cipto, H., \& Suriadiredja, A. Tumor kulit. Dalam: Menaldi SL, Bramono K, Indriatmi W, editor. Ilmu penyakit kulit dan kelamin (Ketujuh). FKUI. 2018.

[8] Sibarani, M., Dalimunthe, D., \& Putra, I. Tumor kulit di Poliklinik Kulit dan Kelamin RSUP H. Adam Malik Medan. Palembang. 2011

[9] SCF. All about Sunscreen. 2019. Diambil dari Internet website: https://www.skincancer.org/skin-cancer prevention/sun- protection/sunscreen/

[10] Notoadtmodjo, S. 'Promosi Kesehatan dan Ilmu Perilaku'. No.: Rineka Cipta Lavi N, Novita. SUNSCEEN FOR TRAVELLERS. E-Jurnal Medika Udayana 2010. [S.l.], 1046-1056. https://doi.org/2303-1395

[11] Nursalam. Metodologi Penelitian Ilmu Keperawatan Pendekatan Praktis Edisi.4. Jakarta : Salemba Medika. 2016. 
[12] Makhmudah, S. Hakikat Ilmu Pengetahuan dalam Perspektif Modern dan Islam', AL-MURABBI. Jurnal Studi Kependidikan dan Keislaman. 2017. 4(2), 202-217. https://doi.org/0.53627/jam.v4i2.3173

[13] Pramesti, et al. Universitas Islam Negeri Syarif Hidayatullah No. Angkatan 2016 Terhadap Penggunaan Tabir Surya. 84. 2019.

[14] Wadoe, M., \& et al. Penggunaan Dan Pengetahuan Sunscreen Pada Mahasiswa Unair. Jurnal Farmasi Komunitas. 2020. 6(1), 1. https://doi.org/10.20473/jfk.v6i1.21821

[15] Tranggono, Retno, I., Latifah, \& Fatma. Buku Pegangan Ilmu Pengetahuan Kosmetik. Jakarta: PT. Gramedia Pustaka Utama. 2007

[16] Juanita, R. ., \& Juliadi, D. PENETAPAN POTENSI TABIR SURYA KRIM EKSTRAK ETANOL DAUN CEREMAI (Phyllanthus acidus L.) DENGAN SPEKTROFOTOMETRI UV-VIS. Jurnal Farmagazine 2020. 7(1), 51. https://doi.org/10.47653/farm.v7i1.154

[17] Badan Pengawas Obat dan Makanan Republik Indonesia. Naturakos. 2009. Vol. IV/No. 11, ISSN: 1907-6606.

\section{AUTHORS}

First Author - Aulia Annisa Manurung, Faculty of Medicine, Universitas Sumatera Utara, Medan, North Sumatera, Indonesia. auliaannisam@gmail.com

Second Author - Ariyati Yosi, Department of Dermatology and Venereology, Faculty of Medicine, Universitas Sumatera Utara, Medan, North Sumatera, Indonesia

Correspondence Author - Imam Budi Putra, Department of Dermatology and Venereology, Faculty of Medicine, Universitas Sumatera Utara, Medan, North Sumatera, Indonesia

Correspondence Author - Imelda Rey, Department of Internal Medicine, Faculty of Medicine, Universitas Sumatera Utara, Medan, North Sumatera, Indonesia 